\title{
Social Entrepreneurship and Corporate Social Responsibilities
}

\author{
Catalina Mitra Crisan (Corresponding author) \\ Faculty of Economics and Business Administration, Babes-Bolyai University \\ Theodor Mihali Street, No. 58-60, 400591, Cluj-Napoca, Romania \\ Tel: 40-264-418-654Ｅ-mail: mitracatalina@yahoo.com \\ Anca Borza \\ Faculty of Economics and Business Administration, Babes-Bolyai University \\ Theodor Mihali Street, No. 58-60, 400591, Cluj-Napoca, Romania \\ Tel: 40-264-418-654Ｅ-mail: anca.borza@econ.ubbcluj.ro
}

Received: December 5, 2011

doi:10.5539/ibr.v5n2p106
Accepted: December 13, 2011 Published: February 1, 2012

URL: http://dx.doi.org/10.5539/ibr.v5n2p106

\begin{abstract}
This article emphasizes the meaning of social entrepreneurship and that of corporate social responsibility and the role held in social value creating process. There are several opinions regarding the distinctions between social entrepreneurship and corporate social responsibility considering the implications, the impact and the stimulus. This article will point out our approach regarding Social Entrepreneurship and Corporate Social Responsibility based on our research made in Cluj County from northwestern part of Romania, by highlighting their characteristics and the way that both processes influence the social environment. The research was made using two types of questionnaires which were applied to commercial enterprises and NGO's with social purpose.
\end{abstract}

Keywords: Social entrepreneurship, Corporate social responsibility, Cluj

\section{Theoretical Approach}

\subsection{Corporate Social Responsibility}

Corporate Social Responsibility (CSR) brings many benefits being considered an important lever in supporting social entrepreneurship (Austin 2007, Austin et all, 2006, Austin, et al., 2004, Austin and Reavis 2002, Austin, 2000). Also, CSR has a significant role in the social value creation process for both, businesses and social purpose organizations. The concept of corporate social responsibility is a broad term being used in various forms such as corporate citizenship, corporate social involvement or community, corporate philanthropy. CSR policies help firms to fulfill economic and social responsibilities ensuring wellbeing and social welfare (Hockerts, 2007). CSR policies can be considered as being companies' commitment to improve society through business practices (Kotler and Lee, 2005). It refers to sustainable economic development working with employees and their families, local community and society as a whole, in order to improve their standard of living (World Business Council for Sustainable Development, 2004).

CSR policies are seen as being "business decisions" that pass beyond the economic and technical interests of the organization (Carroll, 1991). CSR initiatives are major activities undertaken by a firm in order to sustain social causes and to fulfill its commitment to corporate social responsibility. It covers areas like: health (AIDS, cancer), safety (crime prevention), education (education for those in need), job creation (training practice) environment (recycling) economic and social development (low interest loans for purchase of apartments), and it meets other basic human needs and desires (combating hunger, poverty, discrimination) (Wills, 2009).

Social involvement is a corporative integrative function of the company involving practices that contribute to the establishment of positive relationships with communities and society at various levels (Waddock, 2004). The approach given by the International Business Forum (2003) and Tracey et all (2007) assumes that corporate social involvement means the investing collaboration relations and partnerships with non-profit and public sector in order to create healthy and favorable conditions, targeting both, community and business. Businesses can help significantly social organizations trough partnerships. This can happen either through a department of an entrusted 
organization, as a department within the corporation or by a team of representatives of different companies (Wills, 2009).

Through CSR a company seeks to minimize risks and adverse effects maximizing economic and social benefits, it establishes relationships based on trust to promote progress in accordance with ethical principles and moral values institutionalization and it supports its financial and economic values (Corporate Citizenship Report, 2005).

Although definitions abound, we can say that two main directions can be highlighted, that CSR policies can be developed as standalone project or networking with other companies and social organizations targeting groups such employees, customers, nonprofit organizations, public authorities, the media.

\subsection{Social Entrepreneurship}

In the field of social affairs, researchers have demonstrated the importance of social entrepreneurs to solve social problems in relation to the state, having the role to endorse social entrepreneurship (social enterprise, NGOs with social cause). Social entrepreneurship is defined the way of using resources to create benefits for the society and the social entrepreneur is the person who seeks to benefit society through innovation and risk taking (Tracey et all, 2007). Thus, social entrepreneurship is the field that allows observation of how social problems can be solved in a sustainable way. Many approaches to social entrepreneurship sustain that the emphasis is actually on the individual more than on a collective model (Bornstein, 2007, Austin et al., 2007, Dees et al., 2001a,b, Leadbeater, 1997). Thus, social entrepreneurs identify what does not work inside society, trying systematically to impose change on different social levels, without giving up before achieving the expected goal (Drayton, 2002). Social Entrepreneurship arises when people run by social mission, act better than competitors driven by the entrepreneurial behavior (Mort et all, 2003). Hartigan (2006) believes that social entrepreneurship follows the transformation of entrepreneurship in a progressive way. This definition involves entirely new models, innovative, ingenious ones based on identifying opportunities. Casson (1982) shows that social entrepreneurship can be seen as a process met both in private and public sector. Many authors have given various nuances to the concept (Bornstein 2005, Nicholls 2006, Light 2008, Elkington and 1994). Korosec and Berman (2006) include social entrepreneurship in the process of individuals or of the private organizations that have the initiative to identify and solve social problems, in order to develop new ways of solving social problems. From this perspective social entrepreneurship identifies opportunities, collaboration and teamwork, social corporate involvement and the adaptation of business principles to social issues. In Romania, the Ministry of Labor, Family and Social Protection uses for the term social entrepreneurship the notion of social economy, which refers to a group of people gathered in order to undertake an active economic role in the process of social inclusion, NGOs (foundations and associations) and other non-profit organizations that have an important role in social value creation.

Social entrepreneurship is mainly found as an interaction between NGO's and other organizations, through self-sustainable and independent activities that are constantly changing economic and legal framework within a country. However, where there is adequate collaboration between the private sector that has the experience and ability to develop the commercial side of social organizations several forms of organization can be developed with different social outcomes.

\section{Research Methodology}

Interdisciplinary character of our research is confirmed by two relevant models. Thus the model developed by Tracey et all (2007) deals with four distinct forms of cooperation between enterprises and organizations with social mission, (charitable contributions, the enterprise internal projects, collaborations and partnerships), giving simultaneously an overview of the interface area of Corporate Social Responsibility and social entrepreneurship. Also Seitanidi (2008) emphasizes the existence of three forms of partnership across sectors, namely: public-private partnerships, public- non-governmental organizations and private partners-NGOs. Professor Rob John, supported by the Skoll Center for Social Entrepreneurship at Oxford Said Business School has treated in detail the relationships between organizations and social entrepreneurs who assist them. The survey had a structured form and was based on two questionnaires adapted to enterprises and NGOs considering the criteria of social entrepreneurship (Borza et al, 2009). The data collection process was made indirectly through e-mails and was implemented at top management level of businesses and NGOs. To increase the response rate of organizations in the survey, we also used direct interviews. The study is focused on identifying the way that NGOs and commercial enterprises sustain social entrepreneurship and emphasis the differences and similarities between social involvement among companies and NGOs.

Research Hypotheses pursued during the research

General Hypothesis: 
1. Social Entrepreneurship is a real phenomenon that has applicability in the current social environment in Cluj

2. Social entrepreneurship and corporate social responsibility are clearly distinguishable but have a common aspect given by the social impact.

\section{Secondary Hypotheses}

1. Social involvement is seen by companies more as an obligation rather than as an act of will.

2. Large enterprises have a greater susceptibility to implement CSR practices.

3. CSR practices are regarded as a mean for acquiring competitive advantage.

4. The main problems in promoting social entrepreneurship in Romania is given by law, bureaucracy, and lack of support.

5. The groups targeted by enterprises and NGOs are disabled people, minorities, elderly.

Based on these hypothesis we investigate all NGOs active in the range of Cluj County. Simultaneously a random probabilistic sampling was conducted. Using the Taro Jamane method, we established a sample of 394 enterprises, excluding family associations and individuals and 234 NGOs as sample base. We obtained a response rate of $20 \%$ from enterprise, evidenced by 79 of the questionnaires and a response rate of $31 \%$ from NGOs, materialized in 76 questionnaires.

Research restrictions were the low rate of responses that required an extension of time for data collecting, the increased reluctance among business representatives to provide an input, the failure to timely existing records held by the competent organs at county level as well as the lack of the empiric research in the field.

\subsection{The Structure of the Commercial Enterprise Sample}

The legal form of companies included in the sample has the following structure: $79 \% \mathrm{Ltd}, 19 \% \mathrm{Plc} 2 \%$ other. The number of employees included in the sample companies allowed us to classify them in micro enterprises (32 enterprises), in small (24 enterprises), in medium (13 enterprises) and large (10 enterprises). Most enterprises were created after 1990. Taking into account the geographical coverage where they operate, we noticed that about $27 \%$ have an international activity, $38 \%$ a national activity, and $16 \%$ a local one. At the international level, the most frequently mentioned countries were: France, Germany, Italy, Austria, Spain, Korea and USA. The companies included in the sample operate in a regional area, mostly in Transylvania and Banat. Also $75.6 \%$, of the companies involved in the research are independent organizations $6.4 \%$ parent organization and $18 \%$ subsidiaries.

\subsection{The Structure of the NGO's Sample}

The legal form of NGOs included in the sample has the following structure: $64 \%$ are Associations, $28 \%$ Foundations, $4 \%$ Trading Companies, $4 \%$ other. Approximately $80 \%$ are focused on communities' problems, consultancy and social service while the rest were focused on protecting the environment and production. An expected issue was confirmed by the fact that the grate majority of NGOs were created after 1989. Since then the number of NGOs registered a significant boom reaching over 2000, meaning that their number has increased by threefold. Also $75.9 \%$ of NGOs have up to 10 employees and $97 \%$ have up to 10 part-time employees, $52.7 \%$ had up to 10 volunteers. Given the sample 60 of the organizations are independent, 3 of which are parent organizations and only 13 were subsidiaries. Of the total independent organizations, 18 have a range of international action, 12 national, 10 regional and 18 local action. Given the fact that independent organizations have the greatest weight, it can be observed that half of them have an impact covering an extended area (international and national). The independent organizations have a greater degree of flexibility and a much higher impact compared to the parent and subsidiary organizations.

\section{Results of the Researches}

\subsection{Enterprises from Cluj County}

\subsubsection{Social Mission}

Regarding the elements that characterize the mission of a company, the obtaining of profit was for $88.4 \%$ of the respondents the most important. Creating new jobs for $15.2 \%$ of respondents is not an element of their mission, $13.9 \%$ have shown that this is important only to a very limited extent and only $12.7 \%$ have indicated that this element is important. We observed that innovation has a low importance for most of the enterprises, taking into account that the majority of the respondents are SMEs. This is considered truly negative, since it is known that SMEs are those ones which should promote innovation (Borza et all, 2009). Regarding the use of non-conventional resources, only $8.9 \%$ of the respondents considered as being an important matter in a very large extent. Based on these results we believe that the firms do not show an increased interest for unconventional resources and for 
innovation. Although non-conventional resources are considered extremely important in developed countries, our results confirm the opposite.

\subsubsection{The Involvement of the Enterprises to Employ Disadvantaged People}

Companies have a reticence regarding employing minorities or the employing of people with disabilities. This can be noted by the fact that $67.1 \%$ of respondent companies have no employees with a disability; only $29.1 \%$ have between 1 and 4 employees with disabilities and 3.8\% between 5 and 9 employees with disabilities. Also, 50.6\% of the firms have no minorities as employees. There is a limited availability of enterprises to include people with disabilities, former prisoners, former drug addicts, homeless people and Romani people. Thus $86.1 \%$ claimed that they would not hire former prisoners, $93.7 \%$ would not employ former drug addicts, $89.9 \%$ would not employ homeless, $81 \%$ would not hire Romani people and $75.9 \%$ would not employ people with disabilities. Under this circumstance the chances for this people to find employment are very low. Also, $44 \%$ consider that this type of resources would not be used under no circumstances, $19 \%$ believed that they would accept to take use of such resources only if the state would provide financial incentives, $5.1 \%$ only if they would be forced by circumstances, and $7.6 \%$ if they will not have other alternative. Only $24 \%$ believed that these could have potential, but it could also dependent on the field and the business.

\subsubsection{Enterprise' Economic Activity}

Analyzing the business strengths, the majority of the respondent companies considered marketing and sales, human resources management, less important were $\mathrm{R} \& \mathrm{D}$ and the access to funding. Marketing and sales are considered by most companies as being relevant since more than $50 \%$ of the respondent companies are in the field of services. Taking into account the additional income sources from which companies can gain access, we observed that for more than $80 \%$ of the respondents, donations are not a source of additional income. Governmental grants are not a source of additional income according to $70.9 \%$ of respondents, and also funding projects were considered by $74.7 \%$ as not being a source of additional income.

\subsubsection{Social Involvement}

Approximately $21.6 \%$ of the respondent companies have indicated that they are not involved in socially responsible activities and only $2 \%$ mentioned that were involved before 1990 . The remaining $76.6 \%$ specified that they were socially involved after 1990. As expected, all firms that started their social activities after 1991 but mainly after 2000.

\subsubsection{Advantages and Disadvantages Resulting from Social Involvement}

Also 78\% have shown that this involvement has not brought economic benefits to enterprises. Only an amount of $22 \%$ noted that social involvement brought benefits. The mentioned benefits were the following: $28 \%$ increased reputation, approximately $12 \%$ have indicated that they influenced sales growth, $20 \%$ felt that it adds value to the company, $40 \%$ have shown that social involvement brings owner satisfaction. Based on the question which seeks to identify social disadvantages arising from the involvement of companies, we have found that $58.9 \%$ of the respondents considered the total cost increased as the main disadvantage, $30.4 \%$ considered the use of additional resources and $12.5 \%$ considered that decreases the efficiency. From a total of 55 valid responses to the question about the problems faced when providing the support was mentioned bureaucracy by $47.3 \%$ of the respondents, $23.6 \%$ mentioned legislative restrictions, $12.7 \%$ difficulties in attracting volunteers.

\subsubsection{Social Impact}

The final purpose of the social activities of the enterprises emphasized that the main groups were people with disabilities, children and youth and the local community. The financial support is preferred than the material one. However, there were other forms of assistance such as providing food and clothing and offering jobs to those in needs, but they acquired a low percentage. The assessment of the social impact does not represent a significant concern for enterprises that engage socially. But among those who have such a method, most of them have specified that the amounts allocated and the scope of the results give an idea of social involvement.

\subsubsection{Partnership with NGOs}

Also, $74 \%$ of the respondents have indicated that they would not make a partnership with NGOs to achieve social responsibility policies. The rest agreed on the idea of having a partnership with an NGO, they have chosen as a means of collaboration the following: $22 \%$ agree with the establishment of a partnership, $20 \%$ would work on long term with an NGO, $3 \%$ would create a foundation on its own initiative, $35 \%$ have indicated that they will establish a partnership only if the NGO would be the beneficiary, $10 \%$ believed it would work only if the social activities would be complex, and only $10 \%$ have worked in order to increase the social impact. 
Among the benefits of having a partnership with an NGO, companies considered owner satisfaction as being the biggest advantage of these collaborations, followed by rising notoriety and by a good relationship with the social sector. We noticed that these companies had a strong policy regarding social responsibility activities sustained on long term. Corporate social responsibility is considered by some companies as a competitive advantage and considering this fact we observed that most of the respondents would react if other firms would develop a competitive advantage in a similar area. This response is expected especially because we can talk about the commercial area where only the best companies can win.

\subsection{NGO's of Cluj County}

\subsubsection{Social Mission}

All the NGOs included in the survey had a social mission.

\subsubsection{The Employment of Disadvantaged People}

Our study underlines that women feel more ready to engage in NGOs than men. Approximately $74.6 \%$ of the NGOs have fewer than 10 full-time employees, $15.3 \%$ of them have between 11 and 20 full-time employees. It is considered that NGOs create social value and employment opportunities for people with disabilities, minorities or the socially excluded. We observed that the number of disabled people employed by NGOs was lower than the number of the minorities employed by these organizations. We can deduce that the vast majority of the NGOs do not have a significant number of employees, financial restrictions being this one of the main reasons. However, the necessary labor is completed in a significant extent through voluntary acts.

\subsubsection{The Economic Activity of the NGO}

The sources of income, which the NGOs base on, are made up of donations, economic activities, state subsidies and funding projects. Thus, we observed that donations and funding projects provide a significant contribution to total revenues of the NGOs. Another aspect to be noted is that there are organizations which undertake economic activities that provide up to $100 \%$ of total revenues. This fact points out that NGOs are not indifferent to the advantages that arise from economic activities. Also the vast majority of the NGOs have shown that donations mostly come from external sources. Among the activities that generate the highest revenue are the following: education $62.3 \%$, counseling $29.6 \%$, health $32.4 \%$, manufacturing $18 \%$, tourism $18.3 \%, 17 \%$ arts.

\subsubsection{Social Involvement}

The results have shown that NGOs sustain competitiveness. When the respondents were asked about their predisposition to collaborate with other NGOs acting in the same area, only $25.7 \%$ considered that it would bring a lot of benefits, $59.5 \%$ of the respondents claimed that they would try to be more competitive and only $14.8 \%$ claimed that they would be indifferent. It is surprising that most respondents are against alliances, especially considering their mission to promote social cause. But this highlights a positive aspect, namely the desire to be better than rivals, something which can lead to higher powers and an increased social impact. Among those who argued that activity they carried out made a difference through a new product, $83.3 \%$ of them would try to become more competitive while only $16 \%$ would establish a partnership with competitors. The study reveals that a fairly large proportion of the total NGOs that bring something new through the resourced used did not show a great interest for innovation. This means that they do not show a real concern for conservation and rationalization of resource consumption.

\subsubsection{Advantages and Disadvantages of Social Involvement}

Analyzing the support received by NGOs from local authorities, social purpose organizations, the local community, businesses, family and friends of the NGOs representatives we observed that approximately $75 \%$ of respondents considered that local authorities do not play a major role in providing the necessary help. Family and friends of NGOs representatives play a significant role. The local community also pays a particular contribution to NGOs, but none of the respondents considered it as being a very important one. Regarding the business sector, we noticed that $65 \%$ of the respondents consider the help provided by this as being important only in a small and a very small extent. For a deeper analysis we wanted to see the way that banks, investors, customers, suppliers and consulting firms are sustaining NGOs. Most of the respondents classified the support given by these actors from the business environment as being not important. Even so, we have observed that banks, clients and consulting firms have a greater contribution than the rest. The main concerns regarding the fund rising are given by the lack of funding, the bureaucracy and the lack of experience. These cases are not surprising, considering the fact that NGOs face many difficulties and limitations reaching a self-sustainable statute. Not having the required resources at the proper time brings many problems such as attracting qualified staff, holding the necessary resources to streamline the social impact, etc. Bureaucracy is also another major cause of the difficulties faced by NGOs given the uncertainty and 
ambiguity of the legal framework and the limits imposed by the incorrect application of law.

\subsubsection{Social Impact}

NGOs are primarily oriented towards solving problems of disabled people, local community, children and young people.

\section{Insert Figure 1 Here}

Compared to companies, the target groups such as prisoners, people with difficulty in training, unemployed, and refugees are not considered high interest groups. Most of the NGOs measure social impact trough quantitative measures such: quantifying the number of the people helped and the amount spent with the social cause. Unfortunately the measures used are focused on evaluating short term impact.

\section{The Implications of the CSR in the Process of Social Entrepreneurship}

Social involvement of commercial enterprises is a practice that can start either from the existing theory in this field or from experience of other companies, however most things are learned from the experience of conducting business as a result of social responsibility programs. Certainly social involvement is achieved gradually from initiatives that do not involve too many resources and may lead in time to sustain social entrepreneurship through the establishment of organizations developed to work effectively and to support social causes. Perception of social involvement by citizens is often marred by mistrust and suspicion which is a challenge for many companies. Unfortunately the desire to be competitive puts an intense pressure on the enterprises, considering their social involvement as a resource that consumes far too much. So when the involvement in projects does not bring a contribution to enterprise's development, human and material resources allocated to social responsibility motivation and effort is minimized or even eliminated. This situation is somehow justified in the context in which businesses conducts activities oriented towards profit rather than towards charities. To support the involvement of social enterprises one must have a solid economic situation, any social engagement, requiring the mobilization of resources can be allocated for other purposes affecting business prosperity. Taking into account the dimensions of social responsibility leading to competitive advantages such us: risk, efficiency, brand promotion of new markets (Hokerts, 2007), we have observed that companies avoid social involvement to reduce risks. Somehow we can say that it is justified in this context that smaller firms avoid to get involve in social responsible activities because of the lack of the necessary resources. The relationship between social and financial performance affects the competitive advantage of the company, arising from the social responsibility programs undertaken. This type of programs can help companies to gain a competitive advantage.

Companies can sustain social entrepreneurship, being trigger factor of social entrepreneurship. This can be done through collaborations, partnerships, or through putting the basis for creating a social mission organization. Not all organizations that sustain social mission are within the social entrepreneurship spectrum, only those who really meet the criteria of social entrepreneurship (Borza et all, 2009). Organizations that promote social entrepreneurship will get a considerable advantage due to the resources and the support received to sustain social mission and companies will gain notoriety and a positive image with good results over economical activities. Cross sectors collaboration enhance the potential of having a positive effect over social problem solving process. Collaborations throughout the organizations and their partners develop long term projects, permit the change of perspectives, so commercial organizations become more social oriented and social organizations become more commercial oriented. Organizations that sustain social entrepreneurship must recognize the advantages given by commercial activities and therefore trying to become self-sustainable

\section{Conclusions}

Social entrepreneurship is a viable alternative that can cover various forms of organizations, but in our opinion NGOs with social mission provide the premises to sustain social entrepreneurship. Starting from general assumptions, which consists the basis of our research, we concluded that social entrepreneurship is a process that can be identified in the current social environment of Cluj County and that it is manifested mainly in the form of independent organizations wishing to implement innovative practices which allows solving social problems. NGOs and companies create social values using different approach, but we consider that a grater impact will be achieved if these will be inter-correlated, establishing a cause effect manifestation, which increases economical and social performances in both cases. Even if we observed that for most companies philanthropic collaboration is preferred mainly because is the simplest type of collaboration due to the resources and benefits involved, there are some companies, very few, that prefer complex forms of collaborations.

Social entrepreneurship has a grate potential of applicability in Romania, but there is a need for developing supportive facilities to sustain companies to invest in CSR policies, and to increase transparency with the purpose of 
identifying those organizations that really contribute to perpetuation of social entrepreneurship process. Companies have a more specific approach when it comes of choosing the targets compared with NGOs that have a more broad-spectrum. This emphasize that companies chose the target that best fits the mission statement rather than NGO that chose the target based mostly on communities needs.

We observed the fact that companies because of their commercial purpose see social involvement more as an act of will and for grate majority, the decision of getting involved in social causes comes because of owner satisfaction and not necessarily because of the positive impact over the company. Even so large companies were more likely to invest in CSR policies due to greater financial power and because CSR policies are seen a significant policies of gaining competitive advantage. In this case the image on the market tends to have a significant importance and CSR policies are the best mean to strengthen the market position.

The conducted survey emphasizes the particularities of social environment from Cluj County using several criteria with the purpose of observing the way commercial enterprises and NGOs contribute to social value creating process. Based on these two researches we conclude that NGOs have better chances to promote social entrepreneurship starting with the fact that these have first of all a social mission. Also we can say that social entrepreneurship can be sustained by the companies through CSR (partnership, collaboration, founding an organization with a social mission). Corporate social responsibility and social entrepreneurship have distinct conceptual approach, but interferes in the area of recovery of social opportunities.

\section{References}

Austin, J. E., Skillern, J. W., Leonard, H., \& Steverson, H. (2007). Entrepreneurship In The Social Sector, California: Sage Publications.

Austin, J., Gutierrez, R., Ogliastri, E., \& Reffricco, E. (2006). Effective Management of Social Enterprises. Lessons from Business \& Civil Society Organizations in Iberoamerica, Harvard University Press.

Austin, J. E., Jane W. - S., \& Alexis, G.. (2004). Starbucks \& Conservation International. Teaching Note, 304-100, Harvard Business School, Division of Research, Boston.

Austin, J. E., \& Cate, R. (2002). Starbucks \& Conservation International. Teaching Case, 303-055, Harvard Business School, Division of Research, Boston.

Austin, J. E. (2000). The Collaboration Challenge How Nonprofit \& Businesses Succeed Trough Strategic Alliances. London: Peter Druker Foundation.

Bornstein, D. (2007). How to Change the World Social Entrepreneurs \& the Power of new Ideas.

Bornstein, D. (2005). How to Change the World: Social Entrepreneurs \& the Power of New Ideas. Penguin Books: New Delhi, India.

Borza, A., Mitra, C., \& Bordean, O. (2009). Social Entrepreneurship in the Context of the Romanian Transitional Economy, in Complexity Science \& Social Entrepreneurship Adding Social Value through Systems Thinking A Volume in the Exploring Organizational Complexity Series Volume 3, New York.

Carroll, A. B. (1991). The Pyramid of Corporate Social Responsability: Toward the Moral Management of Organizational Stakeholders. Business Horizons, july-august

Casson, M. (1982). The Entrepreneur. Totowa, NJ: Barnes \& Noble Books

Corporate Citizenship Report. (2005). The Center for Corporate Citizenship at Boston College

Dees, J. G. (2001). The meaning of Social entrepreneurship. Available: $\mathrm{http} /$ /faculty.fuqua.duke.edu/centers/case/files/dees-Se.pdf

Dees, J. G., Emerson, J., \& Economy, P. (2001a). Enterprising Nonprofits: A Toolkit for Social Entrepreneurs, John Wiley \&Sons: New York

Dees, J. G., Emerson, J., \& Economy, P. (2001b). Strategic Tools for Social Entrepreneurs: Enhancing The Performance of Your Enterprising Nonprofit: John Wiley \&Sons: New York.

Drayton, W. (2002). The citizen sector: Becoming as entrepreneurial \& competitive as business, California Management Review.

Elkington, J. (1994). Towards the sustainable corporation: Win-win-win business strategies for sustainable development. California Management Review, 36,(2), 90-100.

Hartigan, P. (2006). It's about people, not profits. Business Strategy Review, 17(4), 42-45. http://dx.doi.org/10.1111/j.0955-6419.2006.00433.x 
Hockerts, N. K. (2007). Managerial Perceptions of the Business Case of Corporate Social Responsability, CSR\&Business in Society CBS Working Paper Series no. 03-2007, CBS Center for Corporate Social Responsabiliy, Disertation no. 2750.

Korosec, R. L, \& Berman, E. M. (2006). Municipal support for social entrepreneurship, Public Administration Review, 66(3), 448-462. http://dx.doi.org/10.1111/j.1540-6210.2006.00601.x

Kotler, P., \& Lee, N. (2005). Corporate Social Responsibility. Doing the Most Good for Your Company \& Your Cause, John Wiley \& sons, Inc..

Leadbeater, C. (1997). The rise of Social Entrepreneurship, Demos.

Light, P. (2008). The Search for Social Entrepreneurship, Brookings Institution Press.

Mort, G. S., Weerawardena, J., \& Carnegie, K. (2003). Social entrepreneurship: Towards conceptualization. International Journal of Nonprofit and Voluntary Sector Marketing, 8(1), 76-83. http://dx.doi.org/10.1002/nvsm.202

Nicholls, A. (2006) Social entrepreneurship New model of Sustainable Change, Oxford University Press.

Seitanidi, M. M., \& Crane, A. (2008). Implementing CSR through partnerships: understanding the selection, design and institutionalisation of nonprofit-business partnerships. Journal of Business Ethics, 85(S2), 413-429. http://dx.doi.org/10.1007/s10551-008-9743-y

Tracey, P., Phillips, N., \& Haugh, H. (2007). Beyond Philantropy: Community Enterprise as a Basis for Corporate Citizenship. Journal of Business Ethics, 58(4), 327-344. http://dx.doi.org/10.1007/s10551-004-6944-x

Waddock, S. (2004). Parallel Universes: Academics \& the progress of Corporate Citezenship, Business \& Society Review, 109, 5-42. http://dx.doi.org/10.1111/j.0045-3609.2004.00002.x

Wills, B. (2009). Green Intentions Creating, A Green Value Stream to Compete \& Win, CRC Press Taylor \& Francis Group.

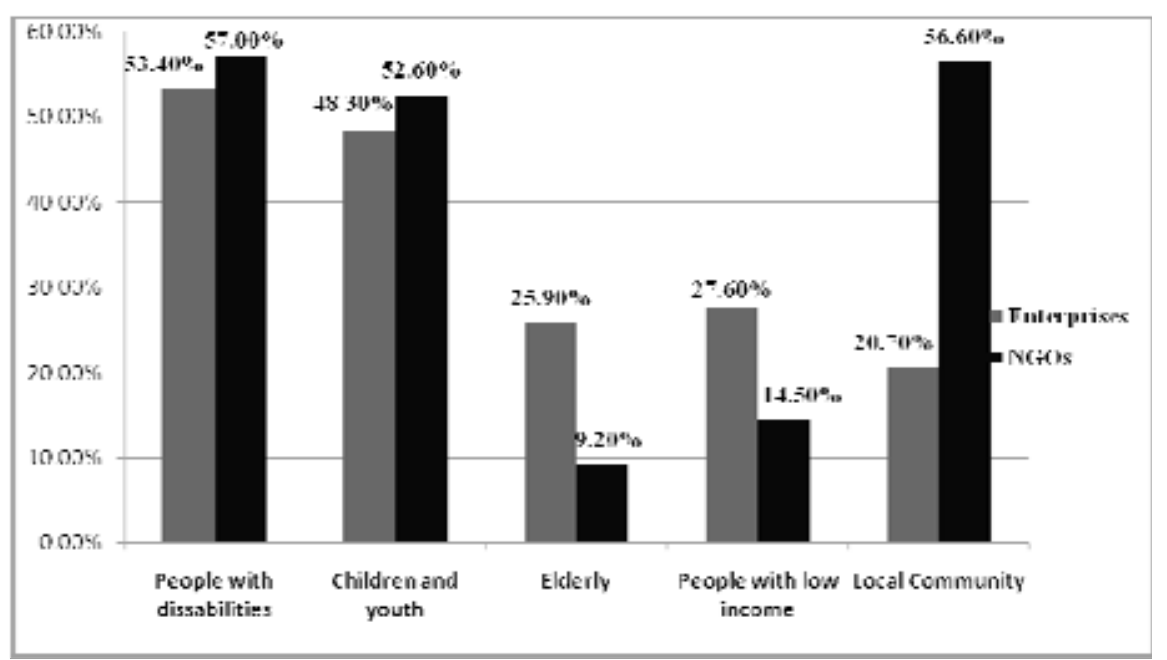

Figure 1. Main Groups Targeted by Firms and NGOs

Making a comparative analysis of the main groups targeted by firms and NGOs we observed that in the case of Peoples with disabilities and Children and youth the tendency is quite similar, these categories being of main interest for both targets. In the case of targets such as elderly and people with low income companies registered higher results that NGOs. A difference is seen in the case of local community were it comes first for NGO with a percentage of 56.60, compared with 20.70 for analyzed enterprises. This emphasizes the fact that companies from Cluj County have a more specialized approach than NGOs. 